\title{
Melanoma: A model for testing new agents in combination therapies
}

\author{
Paolo A Ascierto*1 , Howard Z Streicher ${ }^{2}$ and Mario Sznol ${ }^{3}$
}

\begin{abstract}
Treatment for both early and advanced melanoma has changed little since the introduction of interferon and IL-2 in the early 1990s. Recent data from trials testing targeted agents or immune modulators suggest the promise of new strategies to treat patients with advanced melanoma. These include a new generation of B-RAF inhibitors with greater selectivity for the mutant protein, c-Kit inhibitors, anti-angiogenesis agents, the immune modulators anti-CTLA4, antiPD-1, and anti-CD40, and adoptive cellular therapies. The high success rate of mutant B-RAF and c-Kit inhibitors relies on the selection of patients with corresponding mutations. However, although response rates with small molecule inhibitors are high, most are not durable. Moreover, for a large subset of patients, reliable predictive biomarkers especially for immunologic modulators have not yet been identified. Progress may also depend on identifying additional molecular targets, which in turn depends upon a better understanding of the mechanisms leading to response or resistance. More challenging but equally important will be understanding how to optimize the treatment of individual patients using these active agents sequentially or in combination with each other, with other experimental treatment, or with traditional anticancer modalities such as chemotherapy, radiation, or surgery. Compared to the standard approach of developing new single agents for licensing in advanced disease, the identification and validation of patient specific and multi-modality treatments will require increased involvement by several stakeholders in designing trials aimed at identifying, even in early stages of drug development, the most effective way to use molecularly guided approaches to treat tumors as they evolve over time.
\end{abstract}

\section{Current prospects for melanoma therapy}

The only approved chemotherapy for metastatic melanoma, DTIC, or its oral equivalent temozolomide, has a response rate of about $10 \%$ and a median survival of 8-9 months. The other approved agent for advanced melanoma is high dose interleukin-2, which can induce dramatic complete and durable responses. However, only one patient in twenty derives lasting benefit. Multi-agent combinations [1-7] and bio-chemotherapy regimens [815] were reported to produce much higher objective response rates in phase 2 trials, but did not improve overall survival.

A series of scientific and clinical advances in the past decade has led to a rapid evolution of new treatment strategies. Mutations in B-RAF and c-Kit, have recently been proven to be therapeutic targets in phase 1 clinical trials [16]. Of great potential, a small molecule inhibitor

\footnotetext{
* Correspondence: paolo.ascierto@gmail.com

1 Unit of Medical Oncology and Innovative Therapy, National Tumor Institute, Naples, Italy

Full list of author information is available at the end of the article
}

of B-RAF, PLX 4032, induced tumor regression in $70 \%$ of cases with a 9 month median progression free survival in the $70 \%$ of patients whose metastatic tumors express a specific mutant of B-RAF (V600E). Substantial attention has been focused on the biological mechanisms that led to the success of PLX4032, as other single agent B-RAF and downstream MEK inhibitors were less active [17-19].

Successful results were also reported for imatinib (another kinase inhibitor) in a small but distinct subset of patients with c-kit mutated tumors [20]. Finding additional relevant treatment targets will likely extend the number of patients for whom highly active initial treatment regimens may be chosen.

With regard to biological therapies, the combination of a chemotherapy preparative regimen with adoptive T-cell immunotherapy [21], while technically demanding, has a high response rate, demonstrating the potential efficacy of activated $\mathrm{T}$ cells. In addition, the removal of immunologic inhibition at checkpoints in T-cell activation and effector function by agents such as anti-CTLA4 antibody $[22,23]$ results in tumor regression. These approaches 
may be even more active when combined with other agents that activate or inhibit key molecular regulators of T-cell function [24]. It may be possible to increase the durability of cell signaling agents and enhance the effects of immune-mediated responses if the best way to combine the distinct advantages of each could be identified. Although only a subset of patients achieve durable remissions follow the administration of single biological agents, it been not yet been possible to predict a responsive subgroup to guide patient selection. However, specific activating mutations required for cell signaling inhibitors should not be a limitation. Thus, patient selection for driver mutations, emergence of resistance, timing and durability of responses, and the need for chronic therapy are different but potentially complementary for each modality. It is presently not known whether responders to immunotherapy overlap with responders to targeted agents, but it is likely that most patients would benefit from a combinatorial approaches in which various agents are given together or in sequence.

Combination chemotherapy for cancer was established in the 1960s when the treatment of acute lymphocytic leukemia and lymphoma followed the strategy of antibiotic therapy for tuberculosis in which two or more drugs, each with a different mechanism of action were most effective. In principle, the agents used in the combinations should have additive effects on tumor growth and non-overlapping toxicity. Individual agents used in combination have generally been tested in phase 1 trials to determine the maximal tolerated dose (MTD) and in phase 2 studies at the highest tolerated dose to determine activity based on objective response rates. This sequential approach to drug development is well established, but may not be sufficient to effectively test new promising agents in combination in early phases of development. We may learn from the experience with HAART (Highly Active Anti-Retroviral Therapy) used to treat patients with HIV infection. The discovery of highly potent single drug treatment has lead to dramatic responses but also to rapid drug resistance. Combinations of three or four different antiretroviral drugs, such as nucleoside and nonnucleoside reverse transcriptase and protease inhibitors, block HIV replication and control viral load, reducing the emergence of HIV escape variants and maintaining CD4+ $\mathrm{T}$ cell numbers. Moreover, the recognition that monitoring viral load was a useful surrogate biomarker of viral dynamics, overall treatment efficacy, and survival, allowed drugs to be tested efficiently and more accurately $[25,26]$. The rapid emergence of a multitude of agents with novel targets and mechanisms of action will require changes in the way combinations are developed. In order to effectively validate and expand targeted therapy, the rationale supporting clinical trials design will need to be adapted to keep pace with the opportunities provided by these new agents. Dropping useful agents in early phase single agent development because they may not induce rapid changes in tumor size might be avoided by monitoring effects on specific targets and tumor growth rates. Finding more accurate predictors of biologic activity and overall survival should improve the accuracy of go-no-go decisions for advancing to phase 2 and phase 3 trials [2729]. Understanding molecular tumor biology, pharmacodynamic markers, and imaging technology should lead to the development of biomarkers as trial end points that can help develop active regimes more effectively while reducing the number of unsuccessful studies $[30,31]$.

\section{Early Experience with Molecular Targeted Treatment of Melanoma}

The single activating mutation in B-RAF, V600E, is found at all stages of melanoma, including $70 \%$ of patients with metastatic melanoma [32-34]. The first attempt to use a B-RAF inhibitor, sorafenib, showed little activity in melanoma, and combinations of sorafenib with chemotherapy were not superior to chemotherapy alone in randomized trials [35-37]. However, in a phase 1 study [16], PLX4032, a B-RAF inhibitor with increased specificity for the V600E mutant protein, has demonstrable activity. As exciting as these early results appear, there were no complete responses reported, a third of patients whose cancer bore the target mutation did not respond, and most patients progressed after 9 months. Several mechanisms may be associated with both primary and secondary resistance even with continued inhibition of B-RAF. Almost all resistant tumor will have inactivating PTEN point mutations, over expression of the PI3K/mTOR/Akt pathway, and in addition, feedback loops stimulating downstream pMEK or a switch to the dominance of CRAF. These all suggest possible targets to be included in combination therapy $[38,39]$. It is generally accepted that treatment may need to target both active pathways and it is possible that the combined effects may be measured on a downstream target [40].

To make matters more complex, ATP-competitive RAF kinase inhibitors can have opposing effects depending on the cellular context; growth arrest and apoptosis occur in BRAF ${ }^{\mathrm{V} 600 \mathrm{E}}$ tumors, while in the setting of KRAS mutations and wild type B-RAF, inhibitors can activate the RAF-MEK-ERK pathway enhancing tumor growth $[41,42]$.

Continuing the trend in melanoma, another example of patients selection for targeted therapy is c-Kit mutations., which are often present in acral and mucosal tumors. Treatment with c-Kit inhibitors results in a $50 \%$ or greater response rate [20]. However, as a caution against over generalizations, the activation of non mutated cKIT/SCF in uveal melanoma does not translate into clinical efficacy [43]. This suggests that responses are pre- 
dicted by specific gene mutations and resulting molecular pathogenesis (such as the L576P on exon 11 or the V642E on exon 13) rather than overall protein expression or activation [20]. Common in uveal melanomas, mutations in the G proteins, GNACQ and GNAC11, are more difficult to target than serine kinases and novel biochemical approaches should be sought. New clinical trials based on the discovery of targets, such as the EGFB4 and related activating mutations found in $20 \%$ of patients may increasingly broaden the number of patients that could be treated with a first line highly active agent [44].

\section{Suggestions for combination therapy}

Most advanced tumors have developed multiple growth and survival pathways, so that changing their natural history will require multi-potent treatment strategies. Several publications in the past 5 years have suggested new strategies for designing rational treatment combinations. The idea of limiting growth through inhibition of a single pathway, to which the tumor is "addicted", emerged from clinical trials with imatinib in BCR/Abl CML [45], and cKit in GIST [46], Trastuzumab in Her-2 neu positive breast cancer [47], and more recently, EGFR in a subgroup of patients with non small cell lung cancer [48]. For these agents resistance often develops through selection of escape mutations in the targeted kinase. Identifying these resistance pathways provides an opportunity to change treatment accordingly [49]. In the case of melanoma with the B-RAF mutation, positive feedback loops may paradoxically lead to over expression of inhibited pathways downstream. Combining inhibition of the PI3K-mTOR pathway with MEK inhibitors may effectively treat KRAS mutated lung cancers, making this combination a high priority that was unexpectedly discovered by RNA screening [50]. Another appealing concept takes advantage of the intrinsic vulnerability of a tumor; for example, combining a DNA repair inhibitor of PARP with a DNA damaging agent may greatly enhance effectiveness in tumors that have already lost one pathway of DNA repair. A striking example is emerging in the treatment of patients with BRCA-1 mutations [51-53].

It is worth noting the increasing value of RNA interference (RNAi) in discovery and functional validation for potential therapeutic targets identified through largescale RNAi screens. In fact, gene-specific RNAi provides a powerful tool to demonstrate that specific knockdown of a mutant allele triggers cell death or proliferative arrest in oncogene-dependent cell lines. The tumor specific context, for example of PTEN deficiency with PI3K activation, allows more accurate screening of new agents compared to cells lines with intact PTEN [54,55]. RNA screens may provide unexpected findings that suggest therapeutic combinations in resistant disease. For example, ectopic expression of two genes that act on retinoic acid (RA) signalling can cause resistance to growth arrest and apoptosis induced by inhibitors of histone deacetylase (HDACI) of different chemical classes. This suggests that that the RA pathway may be a rate-limiting target of HDACI which could lead to strategies that enhance the therapeutic efficacy of HDACI [56].

Moreover, for planning therapy, it will be important to distinguish driver mutations from passenger mutations, as recent studies have revealed that many tumors (i.e. human colorectal cancers) undergo numerous genetic and epigenetic alterations. These alterations likely derive from a mixture of "drivers" that play a causal role in tumor development and progression, and "passengers" that have little or no effect on tumor growth. The design of targeted therapeutics may be dependent on the ability to distinguish drivers from passengers $[57,58]$.

\section{Combining signaling inhibitors with other strategies}

Sullivan and Atkins [59] and Palmieri et al. [34] reviewed the use of targeted agents in melanoma and a more general discussion about therapy combinations was provided by Kwak, Clark, and Chabner [60]. Most combinations reported in these reviews involve chemotherapy and often demonstrate how, after safety evaluation in early clinical trials, promising new agents and combinations may stall and never reach the threshold to justify longer, larger, and more expensive trials. Moreover, these trials result in little progress if single agents and empiric combinations are not adequately controlled or analyzed. One advantage of introducing rationally designed combination therapy at an early stage, would be gaining experience in the drug's potential even while single agent development is progressing.

Molecular characterization of the tumor before and during treatment should take a paramount role in trial design particularly when mutations or activated pathways are targeted. Similarly, changes in tumor phenotypes need to be monitored during the natural progression of the disease or in response to the selective pressure exercised by the treatment. Molecular diversity among tumors and within tumors may account for the high degree of variability in response to treatment even in tumor lines with the same primary drivers. Treatment will need to be re-evaluated and changed on a continual basis over time, much as in chronic infections such as for malaria, tuberculosis or HIV. Introducing multiple drugs individually that increase survival by months may not result in prolonged control of the malignant process, but rather in a serial selection of resistant mutant cancer cell populations ever more difficult to control with available therapeutic tools.

Melanoma and renal cell carcinoma have long been held as examples of immunogenic tumors and two kinds 
of immunotherapy, IFN-alpha in the adjuvant setting and IL-2 for metastatic melanoma, are currently approved [61]. Perhaps the most impressive results in the immunotherapy of melanoma are achieved with adoptive transfer of autologous tumor-reactive lymphocytes which can induce rapid objective responses in up to $70 \%$ of recipients, including those with large tumor masses. The activity of adoptively transferred $\mathrm{T}$ cells with recombinant or chimeric receptors has strongly supported this approach [62]. In contrast to the dramatic effects of adoptive T-cell therapy, vaccines have shown far less interesting effects. None the less, a phase 3 trial combining IL-2 with a single melanoma antigen epitope has demonstrated a significant improvement in overall response rate, progression free survival, and a strong trend in improvement of overall survival compared to treatment with IL-2 alone [63]. Interestingly, the response rate induced by the administration of peptide alone was minimal, strongly emphasizing the need to test combinations. Results from an ongoing phase 3 study in which vaccination against Mage-3 is combined with a novel adjuvant are anxiously awaited. The study identified a transcriptional signature in tumors that are likely to respond to vaccine suggesting that even for immunotherapy, predictors of responsiveness could be used in the future for patient stratification [64].

Reversing immunologic suppression by intervention with anti-CTLA-4, and more recently anti-CD40, antiPD-1L, and 1-MT (1-methyl-D-tryptophan) has opened a new door to immune activation against melanoma which can be considered for combinatorial therapy $[65,66]$. Based largely on data from anti-CTLA-4 treatment, reversal of immunologic suppression may have late but prolonged effects in both tumor response and survival presenting another challenge for the evaluation of combination therapy $[67,68]$.

Melanoma cell lines often display constitutive up regulation of anti- apoptotic molecules such as Bcl-2, which may partly account for resistance to chemotherapy. Yet, the combination of DTIC plus oblimersen, anti-sense Bcl-2, had little effect on survival $[69,70]$. Hersey and Zhang [71] have proposed combining pro-apoptotic drugs, with immunotherapy. Their results suggest that within a polyclonal population sensitive cells have predominantly activated the FADD/caspase 8 pathway whereas resistant cells have dominant activation of NF$\mathrm{kB}$ and MEK pathways. Thus, subsets of melanoma cells acquire resistance to apoptosis unless intrinsic anti-apoptotic signaling is interrupted. Up-regulation of the antiapoptotic Bcl-2 family member Mcl-1 is another mechanism critical for protection of melanoma cells against endoplasmic reticulum stress-induced apoptosis [72]. Pro-apoptotic agents have not yet been fully exploited outside of chemotherapy combinations and may consti- tute an important group agent to combine with growth signaling inhibition and immunotherapy [73].

Additionally, some melanomas may be susceptible to treatment with anti-angiogenic agents. When anti-angiogenic agents are used in combination with chemotherapy, the response rate to chemotherapy may be improved [74]. Understanding the mechanisms of resistance to bevacizumab [an antibody that binds to and neutralizes the biologic activity of human vascular endothelial growth factor (VEGF)] may be relevant to its use in combination. It is possible that effects are limited by either intrinsic resistance to bevacizumab in an inflammatory tumor milieu or lack of activity to chemotherapy, so that other combinations with these agents need to be evaluated. In models, vascular disrupting agents that target the established tumor vasculature result in extensive intratumoral hypoxia and cell death. However, a rim of viable tumor tissue from which angiogenesis-dependent regrowth can occur, may depend on mobilization and tumor colonization of circulating endothelial progenitor cells (CEP). Thus co-treatment that blocks CEPs might not result in further tumor regression, but could affect the ability of tumors to continue growth after therapy. Low dose metronomic chemotherapy, such as cyclophosphamide 50 $\mathrm{mg}$ daily, has been proposed as an anti-angiogenic agent which may potentiate the effectiveness of vascular disrupting agents [75].

Another group of promising agents to consider for combination therapy are histone deacetylase (HDAC) and methylation inhibitors; preclinical reports have shown that HDAC inhibitors synergize with cytotoxic agents, such as DNA topoisomerase, imatinib, bortezomib, and various biologic agents. The same studies have shown that when combining agents, the sequence and doses may have a profound impact. As is the case for many biologic agents, the optimal doses for target inhibition may not directly correlate with the traditional maximum-tolerated dose (MTD). A phase I study suggested an impressive response rate in patients with otherwise refractory melanoma, breast, cervical, prostate, and small-cell lung cancer [76]. Other concepts not discussed here but which deserve mention are inhibitors of Notch1, Wnt, and HEDGEHOG pathways and cellular adhesion molecules [77-80].

This discussion is not meant to cover all emerging concepts for the treatment of melanoma, but provides examples of the myriad permutations that may need to be tested in an organized fashion to identify the best possible combinatorial approaches.

\section{Limitations of future trial design and potential solutions}

Drugs such as the B-RAF inhibitors have shown efficacy in early clinical trials, and it is likely they will become 
standard for first line treatment in selected patients. Although these examples provide convincing proof of principle that some of these novel approaches constitute new tools for the treatment of cancer, they have also proven that a single drug is unlikely to induce lasting clinical benefit. New drugs are licensed primarily on the basis of single agent safety and efficacy for a specific clinical indication. Yet once licensed, active drugs such as bevacizumab, trastuzumab, and bortezomib have been available for new uses in combinations, typically in empirically based clinical trials. However, even this less than optimal process, applies only to drugs that are available because of their obvious effectiveness in early trials, which may eliminate many that are likely to work in selected patients or in combination. Thus, the future of therapy will depend on cooperation among various stakeholders and an organized effort to derive the maximum information from clinical trials. This also requires a willingness to share information and minimizing obstacles placed by intellectual property and related financial interests. It is reasonable to expect enlightened self-interest to recognize the need for multiple participants to focus on knowledge gained and the overall benefit of treating cancer patients in clinical trials. A paramount step along the way would be to foster arrangements that could allow more access to agents both for clinical and pre-clinical studies and more complete access and analysis of study results. For many patients, the molecular characterization of melanoma may allow predictive classification for selection of patients entering trials [81]. The ability to utilize effective agents in combination and/or in sequence could allow individualized treatment approaches adapted to a tumor's evolving biology [82]. Trials could be designed and made available for the patient rather than the patient made available for treatment. Thus, it is our hope that in the future appropriate combinations of drugs will be readily available to address the likely limits of single agents as has been successfully done with chemotherapy of some cancers and persistent infections.

\section{Competing interests}

PAA participated to advisory board from Bristol Myers Squibb and GSK; He receives honoraria from Schering Plough and Genta

\section{Authors' contributions}

All Authors: 1) made intellectual contributions and participated in the acquisition, analysis and interpretation of data; 2) have been involved in drafting the manuscript; and 3) have given final approval of the version to be published.

\footnotetext{
Author Details

1 Unit of Medical Oncology and Innovative Therapy, National Tumor Institute, Naples, Italy, ${ }^{2}$ Cancer Therapy Evaluation Program, National Cancer Institute, Bethesda, MD, USA and ${ }^{3}$ Melanoma Program, Yale University School of Medicine, New Haven, CT, USA
}

Received: 4 March 2010 Accepted: 20 April 2010 Published: 20 April 2010
References

1. Costanzi JJ, Al-Sarraf M, Groppe C, Bottomley R, Fabian C, Neidhart J, Dixon $D$ : Combination chemotherapy plus BCG in the treatment of disseminated malignant melanoma: a Southwest Oncology Group Study. Med Pediatr Oncol 1982, 10:251-8.

2. Chapman PB, Einhorn LH, Meyers ML, Saxman S, Destro AN, Panageas KS, Begg CB, Agarwala SS, Schuchter LM, Ernstoff MS, Houghton AN, Kirkwood JM: Phase III multicenter randomized trial of the Dartmouth regimen versus dacarbazine in patients with metastatic melanoma. $J$ Clin Oncol 1999, 17:2745-51.

3. Cocconi G, Bella M, Calabresi F, Tonato M, Canaletti R, Boni C, Buzzi F, Ceci G, Corgna E, Costa P, Lottici R, Papadia F, Sofra M, Bacchi M: Treatment of metastatic malignant melanoma with dacarbazine plus tamoxifen. $N$ Engl J Med 1992, 327:516-23.

4. Rusthoven JJ, Quirt IC, Iscoe NA, McCulloch PB, James KW, Lohmann RC, Jensen J, Burdette-Radoux S, Bodurtha AJ, Silver HK, Verma S, Armitage GR, Zee B, Bennett K: Randomized, double-blind, placebo-controlled trial comparing the response rates of carmustine, dacarbazine, and cisplatin with and without tamoxifen in patients with metastatic melanoma. National Cancer Institute of Canada Clinical Trials Group. J Clin Oncol 1996, 14:2083-90.

5. Falkson Cl, Ibrahim J, Kirkwood JM, Coates AS, Atkins MB, Blum RH: Phase III trial of dacarbazine versus dacarbazine with interferon alpha-2b versus dacarbazine with tamoxifen versus dacarbazine with interferon alpha-2b and tamoxifen in patients with metastatic malignant melanoma: an Eastern Cooperative Oncology Group study. J Clin Oncol 1998, 16:1743-51.

6. Middleton MR, Lorigan P, Owen J, Ashcroft L, Lee SM, Harper P, Thatcher $\mathrm{N}$ : A randomized phase III study comparing dacarbazine, $\mathrm{BCNU}$, cisplatin and tamoxifen with dacarbazine and interferon in advanced melanoma. Br J Cancer 2000, 82:1158-62.

7. Middleton MR, Grob JJ, Aaronson N, Fierlbeck G, Tilgen W, Seiter S, Gore M, Aamdal S, Cebon J, Coates A, Dreno B, Henz M, Schadendorf D, Kapp A, Weiss J, Fraass U, Statkevich P, Muller M, Thatcher N: Randomized phase III study of temozolomide versus dacarbazine in the treatment of patients with advanced metastatic malignant melanoma. J Clin Oncol 2000, 18:158-66.

8. Keilholz U, Goey SH, Punt CJ, Proebstle TM, Salzmann R, Scheibenbogen C, Schadendorf D, Liénard D, Enk A, Dummer R, Hantich B, Geueke AM, Eggermont AM: Interferon alfa-2a and interleukin-2 with or without cisplatin in metastatic melanoma: a randomized trial of the European Organization for Research and Treatment of Cancer Melanoma Cooperative Group. J Clin Oncol 1997, 15:2579-88.

9. Rosenberg SA, Yang JC, Schwartzentruber DJ, Hwu P, Marincola FM, Topalian SL, Seipp CA, Einhorn JH, White DE, Steinberg SM: Prospective randomized trial of the treatment of patients with metastatic melanoma using chemotherapy with cisplatin, dacarbazine, and tamoxifen alone or in combination with interleukin-2 and interferon alfa-2b. J Clin Oncol 1999, 17:968-75.

10. Ridolfi R, Chiarion-Sileni V, Guida M, Romanini A, Labianca R, Freschi A, Lo Re G, Nortilli R, Brugnara S, Vitali P, Nanni O, Italian Melanoma Intergroup: Cisplatin, dacarbazine with or without subcutaneous interleukin-2, and interferon alpha- $2 \mathrm{~b}$ in advanced melanoma outpatients: results from an Italian multicenter phase III randomized clinical trial. J Clin Oncol 2002, 20:1600-7.

11. Eton O, Legha SS, Bedikian AY, Lee JJ, Buzaid AC, Hodges C, Ring SE, Papadopoulos NE, Plager C, East MJ, Zhan F, Benjamin RS: Sequential biochemotherapy versus chemotherapy for metastatic melanoma: results from a phase III randomized trial. J Clin Oncol 2002, 20:2045-52.

12. Keilholz U, Punt CJ, Gore M, Kruit W, Patel P, Lienard D, Thomas J, Proebstle TM, Schmittel A, Schadendorf D, Velu T, Negrier S, Kleeberg U, Lehman F, Suciu S, Eggermont AM: Dacarbazine, cisplatin, and interferon-alfa-2b with or without interleukin-2 in metastatic melanoma: a randomized phase III trial (18951) of the European Organisation for Research and Treatment of Cancer Melanoma Group. J Clin Oncol 2005, 23:6747-55.

13. Bajetta E, Del Vecchio M, Nova P, Fusi A, Daponte A, Sertoli MR, Queirolo P, Taveggia P, Bernengo MG, Legha SS, Formisano B, Cascinelli N: Multicenter phase III randomized trial of polychemotherapy (CVD regimen) versus the same chemotherapy (CT) plus subcutaneous interleukin-2 and interferon-alpha2b in metastatic melanoma. Ann Oncol 2006, 17:571-7. 
14. Middleton M, Hauschild A, Thomson D, Anderson R, Burdette-Radoux S, Gehlsen K, Hellstrand K, Naredi P: Results of a multicenter randomized study to evaluate the safety and efficacy of combined immunotherapy with interleukin-2, interferon-alpha $2 \mathrm{~b}$ and histamine dihydrochloride versus dacarbazine in patients with stage IV melanoma. Ann Oncol 2007, 18:1691-7

15. Atkins MB, Hsu J, Lee S, Cohen GI, Flaherty LE, Sosman JA, Sondak VK, Kirkwood JM, Eastern Cooperative Oncology Group: Phase III trial comparing concurrent biochemotherapy with cisplatin, vinblastine, dacarbazine, interleukin-2, and interferon alfa-2b with cisplatin, vinblastine, and dacarbazine alone in patients with metastatic malignant melanoma (E3695): a trial coordinated by the Eastern Cooperative Oncology Group. J Clin Oncol 2008, 26:5748-54.

16. Garber K: Cancer research. Melanoma drug vindicates targeted approach. Science 2009, 326:1619.

17. Sebolt-Leopold JS: MEK inhibitors: a therapeutic approach to targeting the Ras-MAP kinase pathway in tumors. Curr Pharm Des 2004, 10:1907-14

18. Friday BB, Adjei AA: Advances in targeting the Ras/Raf/MEK/Erk mitogen-activated protein kinase cascade with MEK inhibitors for cancer therapy. Clin Cancer Res 2008, 14:342-6.

19. Montagut C, Settleman J: Targeting the RAF-MEK-ERK pathway in cancer therapy. Cancer Lett 2009, 283:125-34.

20. Carvajal RD, Chapman PB, Wolchok JD, Cane L, Teitcher JB, Lutzky J, Pavlick AC, Bastian BC, Antonescu CR, Schwartz GK: A phase II study of imatinib mesylate (IM) for patients with advanced melanoma harboring somatic alterations of KIT (abstract). Proc Am Soc Clin Oncol 2009, 27:15s.

21. Rosenberg SA, Dudley ME: Adoptive cell therapy for the treatment of patients with metastatic melanoma. Curr Opin Immunol 2009 21:233-40.

22. Weber J: Overcoming immunologic tolerance to melanoma: targeting CTLA-4 with ipilimumab (MDX-010). Oncologist 2008, 13:16-25.

23. Ribas $A$ : Overcoming immunologic tolerance to melanoma: targeting CTLA-4 with tremelimumab (CP-675,206). Oncologist 2008, 13:10-5.

24. Korman A, Chen B, Wang C, Wu L, Cardarelli P, Selby M: Activity of antiPD-1 in murine tumor models: role of 2host" PD-L1 and synergistic effect of anti-PD-1 and anti-CTLA-4 [abstract]. J Immuno/ 2007, 178:48.37

25. Barbaro G, Scozzafava A, Mastrolorenzo A, Supuran CT: Highly active antiretroviral therapy: current state of the art, new agents and their pharmacological interactions useful for improving therapeutic outcome. Curr Pharm Des 2005, 11:1805-43.

26. Verhofstede C, Van Wanzeele F, Reynaerts J, Mangelschots M, Plum J, Fransen $\mathrm{K}$ : Viral load assay sensitivity and low level viremia in HAART treated HIV patients. J Clin Virol 2010 in press.

27. Karrison TG, Maitland ML, Stadler WM, Ratain MJ: Design of phase II cancer trials using a continuous endpoint of change in tumor size: application to a study of sorafenib and erlotinib in non small-cell lung cancer. J Nat/ Cancer Inst 2007, 99:1455-61.

28. Leff $R$, Andrews M: Predicting success in phase III studies from phase II results: a new paradigm is needed. J Clin Oncol 2008, 26:3653-4.

29. Cannistra SA: Phase II trials in journal of clinical oncology. J Clin Oncol 2009, 27:3073-6

30. Rubinstein LV, Dancey JE, Korn EL, Smith MA, Wright JJ: Early average change in tumor size in a phase 2 trial: efficient endpoint or false promise? J Natl Cancer Inst 2007, 99:1422-3.

31. Benjamin RS, Choi H, Macapinlac HA, Burgess MA, Patel SR, Chen LL, Podoloff DA, Charnsangavej C: We should desist using RECIST, at least in GIST. J Clin Oncol 2007, 25:1760-4

32. Davies H, Bignell GR, Cox C, Stephens P, Edkins S, Clegg S, Teague J, Woffendin H, Garnett MJ, Bottomley W, Davis N, Dicks E, Ewing R, Floyd Y, Gray K, Hall S, Hawes R, Hughes J, Kosmidou V, Menzies A, Mould C, Parker A, Stevens C, Watt S, Hooper S, Wilson R, Jayatilake H, Gusterson BA, Cooper C, Shipley J, Hargrave D, Pritchard-Jones K, Maitland N, ChenevixTrench G, Riggins GJ, Bigner DD, Palmieri G, Cossu A, Flanagan A, Nicholson A, Ho JW, Leung SY, Yuen ST, Weber BL, Seigler HF, Darrow TL, Paterson H, Marais R, Marshall CJ, Wooster R, Stratton MR, Futreal PA: Mutations of the BRAF gene in human cancer. Nature 2002, 417:949-54.

33. Curtin JA, Fridlyand J, Kageshita T, Patel HN, Busam KJ, Kutzner H, Cho KH, Aiba S, Bröcker EB, LeBoit PE, Pinkel D, Bastian BC: Distinct sets of genetic alterations in melanoma. N Engl J Med 2005, 353:2135-47.
34. Palmieri G, Capone M, Ascierto ML, Gentilcore G, Stroncek DF, Casula M, Sini MC, Palla M, Mozzillo N, Ascierto PA: Main roads to melanoma. J Trans/Med 2009, 7:86.

35. Hauschild A, Agarwala SS, Trefzer U, Hogg D, Robert C, Hersey P, Eggermont A, Grabbe S, Gonzalez R, Gille J, Peschel C, Schadendorf D, Garbe C, O'Day S, Daud A, White JM, Xia C, Patel K, Kirkwood JM, Keilholz U: Results of a Phase III, Randomized, Placebo-Controlled Study of Sorafenib in Combination With Carboplatin and Paclitaxel As SecondLine Treatment in Patients With Unresectable Stage III or Stage IV Melanoma. J Clin Oncol 2009.

36. Phase III Trial of Nexavar in Chemotherapy-Naive Patients with Advanced Melanoma Does Not Meet Primary Endpoint. Study stopped based on interim analysis 2009 [http:// www.viva.vita.bayerhealthcare.com/ index.php?id $=36 \&$ no cache $=1 \&$ tx ttnews[tt news] $=13136]$.

37. McDermott DF, Sosman JA, Gonzalez R, Hodi FS, Linette GP, Richards J Jakub JW, Beeram M, Tarantolo S, Agarwala S, Frenette G, Puzanov I, Cranmer L, Lewis K, Kirkwood J, White JM, Xia C, Patel K, Hersh E: Doubleblind randomized phase II study of the combination of sorafenib and dacarbazine in patients with advanced melanoma: a report from the 11715 Study Group. J Clin Oncol 2008, 26:2178-85

38. Dhomen $N$, Marais R: BRAF signaling and targeted therapies in melanoma. Hematol Oncol Clin North Am 2009, 23:529-45.

39. Montagut C, Sharma SV, Shioda T, McDermott U, Ulman M, Ulkus LE, DiasSantagata D, Stubbs H, Lee DY, Singh A, Drew L, Haber DA, Settleman J: Elevated CRAF as a potential mechanism of acquired resistance to BRAF inhibition in melanoma. Cancer Res 2008, 68:4853-61.

40. She $\mathrm{QB}$, Solit DB, Ye Q, O'Reilly KE, Lobo J, Rosen N: The BAD protein integrates survival signaling by EGFR/MAPK and PI3K/Akt kinase pathways in PTEN-deficient tumor cells. Cancer Cell 2005, 8:287-97.

41. Hatzivassiliou G, Song K, Yen I, Brandhuber BJ, Anderson DJ, Alvarado R, Ludlam MJ, Stokoe D, Gloor SL, Vigers G, Morales T, Aliagas I, Liu B, Sideris S, Hoeflich KP, Jaiswal BS, Seshagiri S, Koeppen H, Belvin M, Friedman LS, Malek S: RAF inhibitors prime wild-type RAF to activate the MAPK pathway and enhance growth. Nature 2010.

42. Poulikakos PI, Zhang C, Bollag G, Shokat KM, Rosen N: RAF inhibitors transactivate RAF dimers and ERK signalling in cells with wild-type BRAF. Nature 2010.

43. Hofmann UB, Kauczok-Vetter CS, Houben R, Becker JC: Overexpression of the KIT/SCF in uveal melanoma does not translate into clinical efficacy of imatinib mesylate. Clin Cancer Res 2009, 15:324-9.

44. Prickett TD, Agrawal NS, Wei X, Yates KE, Lin JC, Wunderlich JR, Cronin JC, Cruz P, Rosenberg SA, Samuels Y: Analysis of the tyrosine kinome in melanoma reveals recurrent mutations in ERBB4. Nat Genet 2009, 41:1127-32

45. Druker BJ, Guilhot F, O'Brien SG, Gathmann I, Kantarjian H, Gattermann N, Deininger MW, Silver RT, Goldman JM, Stone RM, Cervantes F, Hochhaus A, Powell BL, Gabrilove JL, Rousselot P, Reiffers J, Cornelissen JJ, Hughes T, Agis H, Fischer T, Verhoef G, Shepherd J, Saglio G, Gratwohl A, Nielsen JL, Radich JP, Simonsson B, Taylor K, Baccarani M, So C, Letvak L, Larson RA, IRIS Investigators: Five-year follow-up of patients receiving imatinib for chronic myeloid leukemia. NEngl J Med 2006, 355:2408-17.

46. Papaetis GS, Syrigos KN: Targeted therapy for gastrointestinal stromal tumors: current status and future perspectives. Cancer Metastasis Rev 2010 in press.

47. Dawood S, Broglio K, Buzdar AU, Hortobagyi GN, Giordano SH: Prognosis of women with metastatic breast cancer by HER2 status and trastuzumab treatment: an institutional-based review. J Clin Oncol 2010, 28:92-8

48. Hirsch FR, Varella-Garcia M, Bunn PA Jr, Franklin WA, Dziadziuszko R, Thatcher N, Chang A, Parikh P, Pereira JR, Ciuleanu T, von Pawel J, Watkins C, Flannery A, Ellison G, Donald E, Knight L, Parums D, Botwood N, Holloway B: Molecular predictors of outcome with gefitinib in a phase III placebo-controlled study in advanced non-small-cell lung cancer. J Clin Oncol 2006, 24:5034-42.

49. McCormick F: Future challenges of targeted therapy (abstract). Proceeding AACR-NCI-EORTC International Conference, Molecular Targets and Cancer Therapeutics, Nov 15-19, 2009, Boston, MA. Mol Cancer Ther 2009, 8(Suppl 1):.

50. Brachmann SM, Hofmann I, Schnell C, Fritsch C, Wee S, Lane H, Wang S, Garcia-Echeverria C, Maira SM: Specific apoptosis induction by the dual 
PI3K/mTor inhibitor NVP-BEZ235 in HER2 amplified and PIK3CA mutant breast cancer cells. Proc Natl Acad Sci USA 2009, 106:22299-304.

51. Palma JP, Wang YC, Rodriguez LE, Montgomery D, Ellis PA, Bukofzer $G$, Niquette A, Liu X, Shi Y, Lasko L, Zhu GD, Penning TD, Giranda VL, Rosenberg SH, Frost DJ, Donawho CK: ABT-888 confers broad in vivo activity in combination with temozolomide in diverse tumors. Clin Cancer Res 2009, 15:7277-90

52. Iglehart JD, Silver DP: Synthetic lethality--a new direction in cancer-drug development. N Engl J Med 2009, 361:189-91.

53. Fong PC, Boss DS, Yap TA, Tutt A, Wu P, Mergui-Roelvink M, Mortimer $P$, Swaisland H, Lau A, O'Connor MJ, Ashworth A, Carmichael J, Kaye SB, Schellens JH, de Bono JS: Inhibition of poly(ADP-ribose) polymerase in tumors from BRCA mutation carriers. N Engl J Med 2009, 361:123-34.

54. Rothenberg SM, Engelman JA, Le S, Riese DJ II, Haber DA, Settleman J: Modeling oncogene addiction using RNA interference. Proc Natl Acad SciUSA 2008, 105:12480-4

55. Luo J, Emanuele MJ, Li D, Creighton CJ, Schlabach MR, Westbrook TF, Wong KK, Elledge SJ: A genome-wide RNAi screen identifies multiple synthetic lethal interactions with the Ras oncogene. Cell 2009, 137:835-48.

56. Epping MT, Wang L, Plumb JA, Lieb M, Gronemeyer H, Brown R, Bernards $R$ : A functional genetic screen identifies retinoic acid signaling as a target of histone deacetylase inhibitors. Proc Natl Acad Sci USA 2007 104:17777-82.

57. Starr TK, Allaei R, Silverstein KA, Staggs RA, Sarver AL, Bergemann TL, Gupta M, O'Sullivan MG, Matise I, Dupuy AJ, Collier LS, Powers S, Oberg AL, Asmann YW, Thibodeau SN, Tessarollo L, Copeland NG, Jenkins NA, Cormier RT, Largaespada DA: A transposon-based genetic screen in mice identifies genes altered in colorectal cancer. Science 2009, 323:1747-50.

58. Merlino G: Building the perfect beast: complex mouse models teach surprisingly simple melanoma lessons. Pigment Cell Melanoma Res 2009, 22:246-7.

59. Sullivan RJ, Atkins MB: Molecular-targeted therapy in malignant melanoma. Expert Rev Anticancer Ther 2009, 9:567-81.

60. Kwak EL, Clark JW, Chabner B: Targeted agents: the rules of combination. Clin Cancer Res 2007, 13:5232-7.

61. Eggermont AM, Schadendorf D: Melanoma and immunotherapy. Hematol Oncol Clin North Am 2009, 23:547-64.

62. Johnson LA, Morgan RA, Dudley ME, Cassard L, Yang JC, Hughes MS, Kammula US, Royal RE, Sherry RM, Wunderlich JR, Lee CC, Restifo NP Schwarz SL, Cogdill AP, Bishop RJ, Kim H, Brewer CC, Rudy SF, VanWaes C, Davis JL, Mathur A, Ripley RT, Nathan DA, Laurencot CM, Rosenberg SA: Gene therapy with human and mouse T-cell receptors mediates cancer regression and targets normal tissues expressing cognate antigen. Blood 2009, 114:535-46.

63. Schwartzentruber DJ, Lawson D, Richards J, Conry RM, Miller D, Triesman J, Gailani F, Riley LB, Vena D, Hwu P: A phase III multi-institutional randomized study of immunization with the gp100:209-217(210 M) peptide followed by high-dose IL-2 compared with high-dose IL-2 alone in patients with metastatic melanoma Abstract. Proc Am Soc Clin Oncol 2009, 27:18s.

64. Louahed J, Gruselle O, Gaulis S, Coche T, Eggermont AM, Kruit W, Dreno B, Chiarion Sileni V, Lehmann F, Brichard VG: Expression of defined genes identified by pretreatment tumor profiling: Association with clinical responses to the GSK MAGE- $A 3$ immunotherapeutic in metastatic melanoma patients (EORTC 16032-18031). Proc Am Soc Clin Oncol 2008, 26:

65. Brahmer JR, Topalian SL, Powderly J, Wollner I, Picus J, Drake CG, Stankevich E, Korman A, Pardoll D, Lowy I: Phase II experience with MDX1106 (Ono-4538), an anti-PD-1 monoclonal antibody, in patients with selected refractory or relapsed malignancies (abstract). Proc Am SoC Clin Oncol 2009, 27:15s.

66. Soliman $\mathrm{HH}$, Antonia S, Sullivan D, Vanahanian N, Link C: Overcoming tumor antigen anergy in human malignancies using the novel indeolamine 2,3-dioxygenase (IDO) enzyme inhibitor, 1-methyl-Dtryptophan (1MT) (abstract). Proc Am Soc Clin Oncol 2009, 27:15s.

67. Wolchok JD, Hoos A, O'Day S, Weber JS, Hamid O, Lebbé C, Maio M, Binder M, Bohnsack O, Nichol G, Humphrey R, Hodi FS: Guidelines for the evaluation of immune therapy activity in solid tumors: immunerelated response criteria. Clin Cancer Res 2009, 15:7412-20.
68. Ribas A, Chmielowski B, Glaspy JA: Do we need a different set of response assessment criteria for tumor immunotherapy? Clin Cancer Res 2009, 15:7116-8.

69. Bedikian AY, Millward M, Pehamberger $\mathrm{H}$, Conry R, Gore M, Trefzer U, Pavlick AC, DeConti R, Hersh EM, Hersey P, Kirkwood JM, Haluska FG, Oblimersen Melanoma Study Group: Bcl-2 antisense (oblimersen sodium) plus dacarbazine in patients with advanced melanoma: the Oblimersen Melanoma Study Group. J Clin Oncol 2006, 24:4738-45.

70. Genta Announces Top-Line Results of AGENDA Phase 3 Trial of Genasense" in Patients with Advanced Melanoma 2009 [http:// www.genta.com/Products and Pipeline/Genasense/ Clinical Development.html].

71. Hersey P, Zhang XD: Treatment combinations targeting apoptosis to improve immunotherapy of melanoma. Cancer Immunol Immunother 2009, 58:1749-59.

72. Jiang CC, Lucas K, Avery-Kiejda KA, Wade M, deBock CE, Thorne RF, Allen J, Hersey $\mathrm{P}$, Zhang XD: Up-regulation of $\mathrm{Mcl}-1$ is critical for survival of human melanoma cells upon endoplasmic reticulum stress. Cancer Res 2008, 68:6708-17.

73. Li R, Zang Y, Li C, Patel NS, Grandis JR, Johnson DE: ABT-737 synergizes with chemotherapy to kill head and neck squamous cell carcinoma cells via a Noxa-mediated pathway. Mol Pharmacol 2009, 75:1231-9.

74. Perez DG, Suman VJ, Fitch TR, Amatruda TIII, Morton RF, Jilani SZ, Constantinou CL, Egner JR, Kottschade LA, Markovic SN: Phase 2 trial of carboplatin, weekly paclitaxel, and biweekly bevacizumab in patients with unresectable stage IV melanoma: a North Central Cancer Treatment Group study, N047A. Cancer 2009, 115:119-27.

75. Daenen LG, Shaked Y, Man S, Xu P, Voest EE, Hoffman RM, Chaplin DJ, Kerbel RS: Low-dose metronomic cyclophosphamide combined with vascular disrupting therapy induces potent antitumor activity in preclinical human tumor xenograft models. Mol Cancer Ther 2009, 8:2872-81

76. Carraway HE, Gore SD: Addition of histone deacetylase inhibitors in combination therapy. J Clin Oncol 2007, 25:1955-6.

77. Bedogni B, Warneke JA, Nickoloff BJ, Giaccia AJ, Broome Powell M: Notch1 is an effector of Akt and hypoxia in melanoma development. J Clin Invest 2008, 118:3660-70.

78. Denko N: Hypoxia, HIF1 and glucose metabolism in the solid tumour. Nature Rev Cancer 2008, 8:705-13.

79. Larue L, Delmas V: The WNT/Beta-catenin pathway in melanoma. Front Biosci 2006, 11:733-42

80. Stecca B, Mas C, Clement V, Zbinden M, Correa R, Piguet V, Beermann F, Ruiz i Altaba A: Melanomas require HEDGEHOG-GLI signaling regulated by interactions between GLI1 and the RAS-MEK/AKT pathways. PNAS 2007, 104:5895-5900.

81. Palmieri G, Casula M, Ascierto PA, Tanda F, Cossu A: Molecular classification of patients with malignant melanoma for new therapeutic strategies. J Clin Oncol 2007, 25:e20-1.

82. McDermott U, Settleman J: Personalized cancer therapy with selective kinase inhibitors: an emerging paradigm in medical oncology. $J$ Clin Oncol 2009, 27:5650-9.

\section{doi: $10.1186 / 1479-5876-8-38$}

Cite this article as: Ascierto et al., Melanoma: A model for testing new agents in combination therapies Journal of Translational Medicine 2010, 8:38 